\title{
Simultaneous ammonium and phosphate recovery and stabilization from urban sewage sludge anaerobic digestates using reactive sorbents
}

\author{
M. Hermassiª.b,d, J. Dostac, C. Valderramaa,d, E. Licona, N. Morenoe ${ }^{a}$, X. Querole, N.H. Batis ${ }^{b}$, J.L. Cortinaa,d,f \\ aChemical Engineering Department, Barcelona TECH-UPC, Barcelona, Spain \\ bDepartment of Biological and Chemical Engineering, National Institute of Applied Sciences and Technology \\ (INSAT), University of Carthage, (Tunisia) \\ 'Department of Chemical Engineering and Analytical Chemistry, Universitat de Barcelona (UB), (Spain) \\ dBarcelona Multiscale Science and Engineering Research Center, Barcelona, Spain \\ eInstitute of Environmental Assessment and Water Research IDAEA, Consejo Superior de Investigaciones \\ Científicas, Barcelona, Spain \\ fWater technology Center, CETaqua, Cornellà de Llobregat, Spain
}

${ }^{*}$ Correspondence should be addressed to: César Valderrama

Departament of Chemical Engineering, Universitat Politècnica de Catalunya-Barcelona Tech

C/ Eduard Maristany, 10-14 (Campus Diagonal-Besòs), 08930 Barcelona, Spain

Tel.: 934011818

Email: cesar.alberto.valderrama@upc.edu

\section{Abstract}

The use of low-cost inorganic sorbents as a new sustainable strategy to enhance the valorization of nutrients (N-P-K), from the urban water cycle (e.g., side streams from sewage sludge anaerobic digestion), in agriculture applications is presented. The simultaneous recovery and stabilization of ammonium and phosphate by using a mixture of two reactive sorbents ( $\mathrm{Na}$ and $\mathrm{K}$ zeolites and magnesium oxide) was evaluated. The nutrients stabilization process, favoured at alkaline $\mathrm{pH}$ values, is carried out by a) the precipitation of phosphate ions with magnesium and/or ammonium ions and b) the sorption of ammonium by 
$\mathrm{Na}$ - and K-zeolites. $\mathrm{MgO}(\mathrm{s})$ promoted the stabilization of phosphate as bobierrite $\left(\mathrm{Mg}_{3}\left(\mathrm{PO}_{4}\right)_{2}(\mathrm{~s})\right)$ or struvite $\left(\mathrm{MgNH}_{4} \mathrm{PO}_{4}(\mathrm{~s})\right)$ depending on the applied dose. Doses with the stoichiometric molar ratio of $\mathrm{Mg} / \mathrm{P}$ promote the formation of bobierrite, while molar ratios higher than 3 favour the formation of struvite. Na zeolites (NaP1-NA, NaP1-IQE) demonstrated efficiency on ammonium stabilization between $60 \pm 2$ (for $15 \mathrm{gZ/L}$ ) to $90 \pm 3 \%$ (for 50 $\mathrm{gZ/L}$ ). The ammonium recovery efficiency is limited by the zeolite sorption capacity. If the target of the fertilizing criteria should include $\mathrm{K}$, then the use of a K-zeolite (e.g., 5AH-IQE) provides a good solution. The optimum $\mathrm{pH}$ for the precipitation of struvite and bobierrite is 9.5 and the optimum $\mathrm{pH}$ for ammonium removal is between 4 and 8.5. $\mathrm{N}$ is present in higher concentrations (up $0.7-1 \mathrm{gNH}_{4}+/ \mathrm{L}$ ) when $\mathrm{pH}$ is ranged between 8.2 and 8.6. The ammonium recovery ratios were better than those previously reported using only magnesium oxide or even a more expensive reagent as newberrite $\left(\mathrm{MgHPO}_{4}(\mathrm{~s})\right)$. The recovery mechanisms described generate low-solubility stabilized nutrients forms that potentially can be applied as slow-release fertilizers in agriculture. Thus, the use in agriculture of blends of digested sludge with low-solubility stabilized nutrients forms will improve soils quality properties in terms of organic matter and nutrients availability.

Keywords: nutrients recovery; magnesium oxide; Na-zoelite; K-zeolite; reactive sorbent; sewage sludge anaerobic digestates 


\section{Introduction}

Biosolids (treated and stabilized organic residual by-products) generated from urban wastewater treatment are still an unsolved problem of waste management. In the European Union on average, $40 \%$ of the total biosolids production are applied in agriculture, although the range of utilization varies considerably, from no land application (Netherlands, Slovenia, Slovakia) to $50 \%$ or more (Belgium, France, Denmark, Ireland, United Kingdom, Spain) (Milieu; 2013.). In the case of Spain, almost $76 \%$ of biosolids are applied to land with agriculture being the dominant route (Álvarez et al., 2016).

The use of biosolids, compost, and farmyard manures as fertilizers on agricultural soils as a "waste to resource" option is encouraged as a sustainable alternative to landfilling or waste-energy recovery options. The use of such rich C-based amendments has been common practice in agriculture as they provide high availability of nutrients. However they are under continuous evaluation as to whether it contributes to the accumulation of heavy metals, organic pollutants and phytotoxic compounds (Fabrizio and Fulvia, 2005). As world food resources depend primarily on agriculture, it is predicted that global agricultural production must increase by $70 \%$ by the year 2050 and depletion of carbon and nutrients (N, P, K) contents in the soil are expected (Malingreau et al., 2012).

The supernatant of anaerobically digested sludge is usually returned upstream of primary clarifiers or further treated hence increasing the burden on the treatment plant and the total cost of wastewater treatment (Batstone and Virdis, 2014). In addition, in the sewage treatment system, 20-50\% of phosphorus and 10-30\% of nitrogen in effluent sludge would be returned back to the wastewater treatment system (Fux, 2003). Several technologies have been developed to recover nitrogen and phosphorus from treated water. So far, magnesium ammonium phosphate $\left(\mathrm{MgNH}_{4} \mathrm{PO}_{4}\right.$, struvite) crystallization has been successfully used for simultaneous recovery of nutrients from human urine, swine wastewater, sludge supernatant, and landfill leachate. Its composition makes it a potentially marketable product as a fertilizer of slow-release. Uludag-Demirer and Othman (2008), observed that approximately $63 \% \mathrm{PO}_{4}^{3-}$ and $64 \% \mathrm{NH}_{4}{ }^{+}$could be recovered from the supernatant of anaerobic digestion sludge at pH 9.0 and a Mg/N/P molar ratio 1:1:1. The economic feasibility 
of struvite precipitation is strongly influenced by the reagents cost. The use of $\mathrm{MgO}$ as a magnesium source has as advantages being essential for biological growth, and it provides a suitable $\mathrm{pH}$ for struvite crystallization (Romero-Güiza et al., 2015). Romero-Güiza et al. (2015), evaluated different industrial magnesium oxides (a commercial product and three by-products from magnesite calcination) and total ammonium removal extended from $47 \%$ to $72 \%$, with the poor dissolution kinetics of magnesium oxides as the main limiting step. Natural zeolite and clays have also been used extensively for nutrient recovery and subsequently as fertilizers (Li et al., 2013; Wendling et al., 2013).

Sorption is a simple, economical technology with low-energy consumption that allows the removal/recovery of target solutes from aqueous solutions. Emerging "post-sorption" technologies have been postulated for enabling the recovery of benefit products that can subsequently be used as (i) fertilizers, (ii) catalysts, (iii) feed additives, and (iv) biologically active compounds. As an example, the immobilization of ammonium and phosphate using Ca-activated zeolite as a sorbent has been proven to exhibit great potential (Hermassi et al., 2016a; You et al., 2017). This material is synthesized from coal-fly ashes and presents high cation exchange and sorption capacity, yielding ammonium uptake through ion exchange, and phosphate immobilization by sorption and precipitation of calcium phosphate. Their implementation on the simultaneous removal of both nutrients from treated wastewaters, as post-sorption approach, has been successfully evaluated by the integration of a hybrid process of sorption and membrane separation (Hermassi et al., 2016a; You et al., 2017).

Few studies have been devoted to evaluate the potential application and valorization of powdered reactive mixtures (e.g., industrial by-products), on the simultaneous stabilization of phosphate and ammonium from sludge anaerobic digestates. The purpose for the use of these mixtures is to provide $M g(I I)$ or $K(I)$ ions to promote the formation of mixed phosphates and to stabilize the excess of ammonium by using $\mathrm{Na} / \mathrm{K}$ zeolites. This new strategy ensures the sustainable valorization of N-P-K enriched (post-sorption) sorbents by blending options with the no-methanized biosolid of the anaerobic digester. The biosolid-loaded sorbents blend will contain additionally to a high organic matter content and nutrients (N, P, K) other micronutrients (e.g., Cu, Mn and $\mathrm{Zn}$ ), which improve soil properties and fertility. 
The aim of this study is to identify the optimum ratios of the required reactive sorbents ( $\mathrm{Na}$ - and K-zeolites and magnesium oxide) to achieve the simultaneous stabilization of ammonium and phosphate. The rational of the proposal is taking the benefit of the alkaline $\mathrm{pH}$ values of the anaerobic digestion side-streams where: i) the precipitation of phosphates with ammonium, magnesium, and potassium are thermodynamically favoured, and ii) ammonium exchange properties of the $\mathrm{Na}$ - and K-zeolites will reduce significantly its residual levels in solution. The main stabilization mechanisms will be studied by using solid characterization techniques. The evaluation of the fertilizing and the nutrients release properties of the stabilized products have been not considered at this stage.

\section{Materials and Methods}

\subsection{Materials and solutions}

$\mathrm{Na}^{+}$-zeolite (NaP1-NA) was synthesized from a combustion fly ash with a $3 \mathrm{M} \mathrm{NaOH}$ solution at $125^{\circ} \mathrm{C}$ as described elsewhere (Querol et al., 2007) and its properties on ammonium and phosphate removal have been determined previously (Hermassi et al., 2016a; You et al., 2017). Moreover, two industrial synthetic zeolites in potassium form (5AH-IQE) and sodium form (NaP1-IQE) from IQE (Industrias Quimica del Ebro. Zaragoza, Spain), were used. Magnesium Oxide (>99\% purity-MercK) was also used. The composition of the anaerobic digestion side streams used in the different experiments is described in Table 1.

Table 1. Chemical composition and pH of model water (Anaerobic digestion side-stream) used in the stirred reactor experiments. (Wastewater $\mathrm{pH}: 7.9 \pm .0 .1)$.

\begin{tabular}{ccccccccccc}
\hline Units & $\mathrm{Na}^{+}$ & $\mathrm{NH}_{4}{ }^{+}$ & $\mathrm{K}^{+}$ & $\mathrm{Mg}(\mathrm{II})$ & $\mathrm{Ca}(\mathrm{II})$ & $\mathrm{Cl}$ & $\mathrm{SO}_{4}{ }^{2-}$ & $\mathrm{NO}_{3}{ }^{-}$ & $\mathrm{HCO}_{3}^{-}$ & $\mathrm{PO}_{4}{ }^{--}$ \\
\hline $\mathrm{mmol} / \mathrm{L}^{*}$ & $8.0-10.1$ & $31.8-36.6$ & $0.4-0.5$ & $2.0-1.9$ & $1.3-1.9$ & $33.2-35.5$ & $0.7-0.8$ & $<\mathrm{q}^{* *}$ & $13.2-23.6$ & $1.6-2.9$ \\
& & & & & & & & & \\
\hline $\mathrm{mg} / \mathrm{L}^{*}$ & $185-232$ & $574-660$ & $15-20$ & $48.5-47$ & $51.7-79$ & $1179-1255$ & $69-78$ & $<\mathrm{q}^{* *}$ & $806-1440$ & $156-278$ \\
\hline & & & & & & & & &
\end{tabular}

\footnotetext{
*Values provided are the maximum and minimum concentrations of the different samples collected (typically $50 \mathrm{~L}$ ); ** Iq: limit of quantification
}

\section{$2.2 \mathrm{~N}$ and $\mathrm{P}$ recovery experiments}


The recovery of N-P was performed in a $2 \mathrm{~L}$ glass stirred reactor following the experimental conditions described in Table 2. Agitation at 250 rpm was achieved using a mechanical stirrer (IKA RW 20). The pH was monitored online using a pH potentiometer (Crison $\mathrm{pH} 28$ ). The $\mathrm{pH}$ of solution was fixed dosing $1 \mathrm{M} \mathrm{HCl}$ or $1 \mathrm{M}$ $\mathrm{NaOH}$ using a peristaltic pump when the $\mathrm{pH}$ was 0.1 units above or below the set point. Experiments were performed by mixing fixed amounts of reactive sorbents with the anaerobic digestion side-stream. The first series of experiments (Exp. 1 to 3 in Table 2) was carried out by using the Na-Zeolite (NaP1-NA) and MgO at a constant $\mathrm{pH}$ of 8.5 .

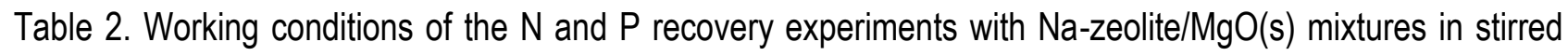
tank reactors ( $1.5 \mathrm{~L}$ of anaerobic digestion side streams).

\begin{tabular}{|c|c|c|c|c|c|c|}
\hline & Stage*I & Stage II & Stage III & Stage IV & Stage V & Stage VI \\
\hline Exp. 1 & $0.067 \mathrm{~g} / \mathrm{L} \mathrm{MgO}$ & $\begin{array}{c}18.3 \mathrm{~g} / \mathrm{L} \mathrm{NaP1-} \\
\mathrm{NA}\end{array}$ & $\begin{array}{l}\text { Constant pH } \\
\quad(8.5)\end{array}$ & - & - & - \\
\hline Exp. 2 & $20.7 \mathrm{~g} / \mathrm{L} \mathrm{NaP1-NA}$ & $\begin{array}{c}\text { Constant pH } \\
(8.5)\end{array}$ & $0.067 \mathrm{~g} / \mathrm{L} \mathrm{MgO}$ & - & - & - \\
\hline Exp. 3 & $\begin{array}{c}0.067 \mathrm{~g} / \mathrm{L} \mathrm{MgO} / 19.7 \mathrm{~g} / \mathrm{L} \mathrm{NaP1}- \\
\mathrm{NA}\end{array}$ & $\begin{array}{l}\text { Constant pH } \\
(8.5)\end{array}$ & - & - & - & - \\
\hline Exp. 4 & $0.4 \mathrm{~g} / \mathrm{L} \mathrm{MgO} / 20.7 \mathrm{~g} / \mathrm{L} \mathrm{NaP1-NA}$ & - & - & - & - & - \\
\hline Exp. 5 & $\begin{array}{c}0.4 \mathrm{~g} / \mathrm{L} \mathrm{MgO} / 20.7 \mathrm{~g} / \mathrm{L} \mathrm{NaP1}- \\
\mathrm{IQE}\end{array}$ & - & - & - & - & - \\
\hline Exp. 6 & $0.15 \mathrm{~g} / \mathrm{L} \mathrm{MgO}$ & $0.067 \mathrm{~g} / \mathrm{L} \mathrm{MgO}$ & $0.033 \mathrm{~g} / \mathrm{L} \mathrm{MgO}$ & $\begin{array}{l}22.3 \mathrm{~g} / \mathrm{L} \\
5 \mathrm{AH}-\mathrm{IQE}\end{array}$ & $\begin{array}{c}6.7 \mathrm{~g} / \mathrm{L} \\
5 \mathrm{AH}-\mathrm{IQE}\end{array}$ & $\begin{array}{c}6.7 \mathrm{~g} / \mathrm{L} \\
5 \mathrm{AH}-\mathrm{IQE}\end{array}$ \\
\hline
\end{tabular}

The second series of experiments (Exp. 4 and 5) was carried out by using two Na-Zeolites (NaP1-NA and NaP1-IQE) by following the sorbents dosing summarized in Table 2. Finally, an experiment using a K-Zeolites (5AH-IQE) and $\mathrm{MgO}$ was carried out to increase the removal ratios of ammonium and phosphate. This last experiment (Exp. 6 in Table 2) included six removal stages: the first three by adding 0.15, 0.1 and $0.005 \mathrm{~g}$ of $\mathrm{MgO}$, respectively, until a phosphate removal ratio was higher than $99 \%$. Then, in the three subsequent stages 50,10 and $10 \mathrm{~g}$ of $5 \mathrm{AH}-\mathrm{IQE}$ zeolite were added.

Samples were withdrawn sequentially at given times to follow the sorption time dependence of N-P ions. After phase separation with a $0.2-\mu \mathrm{m}$-syringe filter, the equilibrium $\mathrm{pH}$ was measured using a $\mathrm{pH}$ electrode (Crison GLP22), and the total phosphate and ammonium concentration were measured. 


\subsection{Analytical methodologies}

The total ammonium, phosphate, bicarbonate, anions, and cations concentrations were determined following the standard methods (APHA, 1999). At the end of the experiments, the solid phase was removed from the reactor by filtration, washed with deionized water several times and dried at $60^{\circ} \mathrm{C}$ for 24 hours. After completing the sorption-filtration experiments, powder samples were examined by FSEM-EDX, and X-ray diffraction as described elsewhere (Hermassi et al., 2016b).

\subsection{Prediction of phosphate precipitation process}

Phosphate and ammonium precipitation using $\mathrm{MgO}$ in the anaerobic side streams were studied using the HYDRA-MEDUSA code (Puidomènech, 2001),(Gray-Munro and Strong, 2013). The measured total $\mathrm{PO}_{4}^{3-}$, $\mathrm{NH}_{4}{ }^{+}, \mathrm{Mg}(\mathrm{II}), \mathrm{Ca}(\mathrm{II}), \mathrm{SO}_{4}{ }^{2-}$ and $\mathrm{HCO}_{3}-$ concentrations were compared to those estimated using the HydraMedusa code when required. Although conditions in the precipitation tests could be far from the equilibrium, measured and predicted values were used to identify the potential reactions and mechanisms involved, especially when the solids formed were not appropriately characterized since their content was below the limit of detection of the analytical techniques used. Equilibrium solubility data for Ca-Mg-phosphates and Mgammonium-phosphates were reviewed from the HYDRA and PHREEQ C databases (Nordstrom et al., 1990).

\section{Results and Discussion}

3.1 Simultaneous stabilization of ammonium and phosphate in urban sewage anaerobic digestate using mixtures of Na-zeolites and $\mathrm{MgO}(\mathrm{s})$

\section{Influence of reactive sorbents addition order on N-P stabilization}

The efficiency of the stabilization of $\mathrm{N}-\mathrm{P}$, with mixtures of $\mathrm{NaP1}-\mathrm{NA}$ zeolite and $\mathrm{MgO}(\mathrm{s})$ under stoichiometric ratios (stoichiometric Mg/P molar ratio 1:1), was not strongly dependent on the reagents addition order and only slightly influenced by the $\mathrm{pH}$ of solution. Table 3 summarizes the overall $\mathrm{N}$ and $\mathrm{P}$ recovery ratios that were ranged between $62 \pm 2 \%$ and $76 \pm 2 \%$ for phosphate for a dose of $0.067 \mathrm{~g} \mathrm{MgO} / \mathrm{L}$ for a digestate stream 
of $1.64 \mathrm{mmol} \mathrm{PO}_{4}{ }^{3-/ L}$, and between $50 \pm 1 \%$ and $60 \pm 3 \%$ for a dose of $18.3 \mathrm{~g} \mathrm{NaP1}-\mathrm{NA} / \mathrm{L}$ for a $32 \mathrm{mmol}$ $\mathrm{NH}_{4}{ }^{+} / \mathrm{L}$.

Table 3. Phosphate and ammonium recovery ratio from an urban sludge anaerobic digestion side-stream as a function of the reagents addition ( $\mathrm{MgO}$ and $\mathrm{Na}-z e o l i t e)$ and at constant $\mathrm{pH}$; (Initial nutrient concentration: 157 $\mathrm{mg} \mathrm{PO}_{4}{ }^{3-} / \mathrm{L}$ and $\left.574 \mathrm{mg} \mathrm{NH}_{4}{ }^{+} / \mathrm{L}\right)$.

\begin{tabular}{cccc}
\hline Experiment & Dosing Order & $\begin{array}{c}\% \mathrm{PO}_{4}^{3-} \\
\text { Recovery }\end{array}$ & $\begin{array}{c}\% \mathrm{NH}_{4}{ }^{+} \\
\text {Recovery }\end{array}$ \\
\hline Exp. 1 & $\mathrm{MgO} / \mathrm{NaP} 1 /$ constant $\mathrm{pH}$ & $76 \pm 2$ & $50 \pm 1$ \\
Exp. 2 & $\mathrm{NaP1/MgO/constant} \mathrm{pH}$ & $65 \pm 1$ & $51 \pm 2$ \\
Exp. 3 & $\mathrm{NaP1}$-MgO/constant $\mathrm{pH}$ & $62 \pm 2$ & $60 \pm 3$ \\
\hline
\end{tabular}

For the three experiments $\mathrm{pH}$ was maintained constant at $8.5 \pm 2$, which yields suitable conditions to achieve ammonium removal and the precipitation of magnesium-phosphates (e.g., bobierrite $\left(\mathrm{Mg}_{3}\left(\mathrm{PO}_{4}\right)_{5} 8 \mathrm{H}_{2} \mathrm{O}\right)$ and struvite $\left(\mathrm{NH}_{4} \mathrm{MgPO}_{4} \cdot 6 \mathrm{H}_{2} \mathrm{O}(\mathrm{s})\right)$. Based on the final measured residual concentrations, the order of addition of the reagents has not affected significantly the phosphorus and ammonium recovery ratios.

The variation of phosphate, ammonium, and $\mathrm{pH}$ as a function of the reaction time along the three reaction stages is shown in Figure 1. The variation of other common ions ( $\mathrm{Ca}, \mathrm{Mg}, \mathrm{Na}$ and $\mathrm{K}$ ) is depicted in Figure $1 \mathrm{~S}$ (Supplementary Material). For Exp. 1, with a dosing order MgO/NaP1/constant $\mathrm{pH}$, during the first stage with the addition of $\mathrm{MgO}(\mathrm{s})$ the phosphate concentration decreased up to $0.28 \pm 0.02 \mathrm{mmol} \mathrm{PO}_{4}{ }^{3-} / \mathrm{L}$ and the concentration of ammonium kept constant at the initial value $33 \pm 2 \mathrm{mmol} \mathrm{NH}_{4}+/ \mathrm{L}$ at a constant $\mathrm{pH}$ between 8.3 and 8.5. Therefore, phosphate recovery could be explained by the formation of a magnesium-phosphate mineral phase as described in Eq. 1, taking into account the concentration changes in the solution where the molar reduction ratio $\left((\right.$ moles $\mathrm{Mg}) /\left(\right.$ moles $\left.\left.\mathrm{HPO}_{4}\right)\right)$ was kept constant approximately at 1.5 .

$3 \mathrm{MgO}(\mathrm{s})+2 \mathrm{HPO}_{4}^{2-}+\mathrm{H}_{2} \mathrm{O} \leftrightarrow \mathrm{Mg}_{3}\left(\mathrm{PO}_{4}\right)_{2}(\mathrm{~s})+4 \mathrm{OH}^{-}$

Eq. 1 
In the second stage of Exp. 1, the addition of $18.3 \mathrm{~g} \mathrm{NaP1-NA} / \mathrm{L}$ lead to the reduction of the ammonium concentration up to $18 \pm 2 \mathrm{mmol} \mathrm{NH}_{4}+/ \mathrm{L}$, which was associated with the $\mathrm{Na}^{+} / \mathrm{NH}_{4}{ }^{+}$exchange as described in Eq. 2:

$\mathrm{NH}_{4}{ }^{+}+\mathrm{Z}-\mathrm{Na}^{+} \leftrightarrow{\mathrm{Z}-\mathrm{NH}_{4}}^{+}+\mathrm{Na}^{+}$ Eq. 2

The ion-exchange reaction was confirmed by following the molar balance of $\mathrm{Na}^{+}, \mathrm{NH}_{4}{ }^{+}$and $\mathrm{Ca}(\mathrm{II})$, since the increase of $\mathrm{Na}^{+}$concentration was related to the decrease of $\mathrm{NH}_{4}{ }^{+}$and $\mathrm{Ca}(\mathrm{II})$. The phosphate concentration was maintained constant and the $\mathrm{pH}$ increased up to 10, as the NaP1-NA zeolite maintained a basic $\mathrm{pH}$, due to a presence of $\mathrm{CaO}(\mathrm{s})$ and $\mathrm{MgO}(\mathrm{s})$ on the former fly ash structure. $\mathrm{pH}$ values higher than the $\mathrm{pKa}$ of the $\mathrm{NH}_{4}{ }^{+}$and $\mathrm{NH}_{3}$ equilibrium at $25^{\circ} \mathrm{C}(9.3)$ diminishes the ion-exchange capacity for ammonium due to the acidbase dependence (Eq. 3). Therefore, in the last stage, $\mathrm{pH}$ was adjusted to 8.5 to favour the presence of $\mathrm{NH}_{4}{ }^{+}$.

$\mathrm{NH}_{4}+\mathrm{OH}^{-} \leftrightarrow \mathrm{NH}_{3}+\mathrm{H}_{2} \mathrm{O}$

Eq. 3

The $\mathrm{pH}$ reduction was traduced in a decrease of the total ammonium concentration that is accompanied in an equivalent increase of $\mathrm{Na}^{+}$concentration in the solution. The reduction of $\mathrm{pH}$ and the $\mathrm{NH}_{4}^{+}$concentration favours the formation of $\mathrm{Mg}_{3}\left(\mathrm{PO}_{4}\right)_{2}$ as it is shown in Figure 2.

Figure 1.

Figure 2.

Figure 2 shows both measured (points) and predicted (solid lines) phosphate concentrations assuming the formation of bobierrite and struvite by using the Hydra-Medusa Code. Solubility curves were calculated as a function of the $\mathrm{MgO}(\mathrm{s})$ added to the reactor from $0.067 \mathrm{gMgO}(\mathrm{s}) / \mathrm{L}$ up to $0.4 \mathrm{~g} \mathrm{MgO}(\mathrm{s}) / \mathrm{L}$. Measured values could be described assuming the formation of bobierrite. As shown in Figure S1.c (Supplementary Material), there is a significant association between the presences of $\mathrm{Na}^{+}, \mathrm{Ca}^{2+}$ and $\mathrm{Mg}^{2+}$ (e.g., a $95 \%$ fulfil the cationexchange balance) with the removal of ammonium and phosphates in the solution. It is worth to mention that the concentration of $\mathrm{Ca}(\mathrm{II})$ was kept constant although the formation of $\mathrm{Ca}(\mathrm{II})$-phosphate minerals as $\mathrm{Ca}_{5}(\mathrm{OH})\left(\mathrm{PO}_{4}\right)_{3}(\mathrm{~s})$ and $\mathrm{Ca}_{3}\left(\mathrm{PO}_{4}\right)_{2}(\mathrm{~s})$ are more stable than magnesium phosphates. According to Romero-Güiza 
et al. (2014), when using caustic magnesia samples containing $\mathrm{MgO}(\mathrm{s})$ as the major component, it was found that the crystallization of struvite over the surface of the $\mathrm{MgO}(\mathrm{s})$ grains was much higher than the observed in this study. For the three experiments, the reduction of the $\mathrm{pH}$ from values of $9.5 \pm 0.2$ up to values of $8.3 \pm 0.2$, in the last stage, lead to a reduction of the bobierrite solubility as depicted in Figure 2.

SEM-EDAX analysis of the reactive sorbent mixtures, at the end of three experiments, exhibited the presence of NaP1-NA as major components of the mixtures. According to its final composition, an increase of the $\mathrm{Mg}$ content with a decrease of the $\mathrm{Na}$ content was observed compared to the raw zeolite composition. The variations on the $\mathrm{N}$ content, associated with $\mathrm{NH}_{4}{ }^{+}$, could not be detected since limit of quantification for $\mathrm{N}$ is very high (>5\% w/w). Morphological (Figure 3a) and EDAX (Figure 3b) analysis identified rich $\mathrm{Mg}, \mathrm{P}$, and $\mathrm{O}$ mineral phases on the surface of the zeolite particles for samples of Exp. 1. Similar results were observed for samples of Exp. 2 and Exp. 3 (see Figure S2 in Supplementary Material).

Figure 3.

XRD analysis of the powdered mixture did not detect any phosphate phase at ambient temperature or after thermal treatment at $1050^{\circ} \mathrm{C}$ (only mineral phases associated with the zeolite were identified). Although the formation of neo-mineral phases are predicted by equilibrium calculations, these were not detected. It should be stated that the presence of amorphous phases or crystalline phases precipitated could not be detected as their content were below the limit of detection due to the high dose of zeolite needed.

Uludag-Demirer and Othman (2008) observed that approximately $63 \% \mathrm{PO}_{4}^{3-}$ and $64 \% \mathrm{NH}_{4}{ }^{+}$could be recovered from anaerobic digestates within $10 \mathrm{~min}$ at $\mathrm{pH} 9.0$ and a $\mathrm{Mg} / \mathrm{N} / \mathrm{P}$ molar ratio of 1:1:1. The formation of other compounds in addition to MAP, such as (newberyite) $\mathrm{MgHPO}_{4} \cdot 3 \mathrm{H}_{2} \mathrm{O}$ or (bobierrite) $\mathrm{Mg}_{3}\left(\mathrm{PO}_{4}\right)_{2} \cdot 8 \mathrm{H}_{2} \mathrm{O}$, among others, were postulated. Romero-Güiza et al. studied the feasibility of coupling anaerobic digestion and ammonia removal in a single stage to enhance methane yields of pig manure through ammonia inhibition mitigation (Romero-Güiza et al., 2015). The five different magnesium sources tested $\left(\mathrm{MgCl}_{2}, \mathrm{Mg}(\mathrm{OH})_{2}\right.$, two industrial by-products rich in $\mathrm{MgO}(\mathrm{s})$ and $\mathrm{MgHPO}_{4}(\mathrm{~s})$ ) provided ammonia reduction to different extents.

\section{Optimization of the N-P stabilization: increasing dosing ratios and modifying zeolite properties}


The increase of the simultaneous recovery of N-P was evaluated by (i) increasing the dosing ratio of Mg/P (3:1) using an excess of $\mathrm{MgO}(\mathrm{s})$, and by (ii) increasing the zeolite dose ratio. Doses of zeolite were determined by predicting the ammonium removal ratios $\left(\mathrm{C} / \mathrm{C}_{0}\right)$ as a function of the contact time and the dosing ratio, for this purpose the homogeneous surface diffusion model (HSDM) (see Annex 1) was used. The $\mathrm{Na}^{+} / \mathrm{NH}_{4}{ }^{+}$ionexchange equilibrium data (e.g., Langmuir constant) and kinetic parameters (particle diffusion coefficient, $D_{s}$, and the liquid film mass transport coefficient, $\mathrm{K}_{\mathrm{f}}$ ) were obtained from previous studies (Hermassi et al., 2016a; You et al., 2017). The variation of the ratio $\left(C / C_{0}\right)$ for ammonium as a function of zeolite dose ( $\mathrm{g}$ Zeolite/L) for different contact times is shown in Figure 4. To achieve $\mathrm{NH}_{4}{ }^{+}$removal ratios higher than $60 \pm 3 \%$, doses higher than $32 \mathrm{~g}$ Zeolite/L should be used and contact times higher than 3 hours. For doses of $60 \mathrm{~g} \mathrm{NaP1-NA/L}$ the contact time dependence shows an increase of the removal ratio of $50 \pm 5 \%$ up to $70 \pm 3 \%$. As the $N, P$ recovery process is proposed to be applied by dosing into the anaerobic digestion reactor, the residence times for the reactive mixtures could be much higher than 3 hours and then maximum removal ratios approaching to the equilibrium values will be reached.

\section{Figure 4.}

Experiments 4 and 5 were carried out working with an excess of $\mathrm{MgO}(\mathrm{Mg} / \mathrm{P}(3: 1))$ and using $20.7 \mathrm{~g}$ zeolite/L (NaP1-NA and NaP1-IQE) in a single addition stage of both reactive sorbents. The results showed a removal ratio of $P$ was higher than $99 \%$ and removal ratios of $N$ between $71 \pm 3 \%$ and $81 \pm 2 \%$, as it was predicted by the HSDM model.

The increase of the $\mathrm{MgO}(\mathrm{s})$ dose up to $0.6 \mathrm{~g} / 1.5 \mathrm{~L}$ was used for the quantitative recovery of $\mathrm{P}$, leaving residual $\mathrm{P}$ concentrations below $0.04 \mathrm{mmol} \mathrm{PO}_{4}^{3-} / \mathrm{L}$. The $\mathrm{P}$ recovery process, although based on a chemical precipitation reaction, is reaching a stationary value in a few minutes. The increase of the zeolite dosing up to $34 \mathrm{~g}$ zeolite/L was used to promote an increase in the $\mathrm{N}$ recovery from $60 \pm 4 \%$ to $80 \pm 2 \%$. No differences were found between both synthetic zeolites after the solid samples analysis. Figure 5 (a, b), depicts Exp. 4 and 5 with both types of zeolites: NaP1-NA to NaP1-IQE, respectively. 


\section{Figure 5.}

Zeolites doses of $34 \mathrm{~g} / \mathrm{L}$ were still insufficient to recover quantitatively (>99\%) the ammonium concentration; however, removal ratios between $78 \pm 2 \%$ and $81 \pm 4 \%$ were achieved. Therefore, the final nutrient concentrations were 0.09 and $0.04 \mathrm{mmol} / \mathrm{L}$ of phosphate, and 6.2 and $7.2 \mathrm{mmol} / \mathrm{L}$ of ammonium with NaP1-NA and NaP-IQE zeolites, respectively. Figure S3 (Supplementary Material), shows the variation of the concentration of the major ions present in the solution. $\mathrm{Na}^{+}$increased as a consequence of the ammonium exchange and an increase of $\mathrm{Mg}(\mathrm{II})$ was also registered due to the excess of $\mathrm{MgO}(\mathrm{s})$, as well as a slight decrease of the $\mathrm{Ca}$ (II) concentration. The $\mathrm{Ca}$ (II) reduction recorded in the first stages indicates a potential removal by the Na-Zeolites, as the $\mathrm{Na} / \mathrm{Ca}$ exchange is favoured more than the formulated removal of phosphate by the formation of calcium phosphates as hydroxyapatite $\left(\mathrm{Ca}_{5}(\mathrm{OH})\left(\mathrm{PO}_{4}\right)_{3}(\mathrm{~s})\right)$, brushite $\left(\mathrm{CaHPO}_{4} 2 \mathrm{H}_{2} \mathrm{O}(\mathrm{s})\right)$, or amorphous calcium phosphate $\left(\mathrm{Ca}_{3}\left(\mathrm{PO}_{4}\right)_{2}(\mathrm{~s})\right)$.

SEM-EDAX analysis (data not shown) of the reactive sorbent mixtures was carried out at the end of the treatment stage and showed NaP1-NA as a major component of the mixtures. In this case, the variations on the $\mathrm{N}$ content, associated with the presence of $\mathrm{NH}_{4}{ }^{+}$were detected. Morphological analysis identified rich $\mathrm{Mg}$, $\mathrm{P}, \mathrm{O}$, and $\mathrm{N}$ mineral phases on the zeolite particles as shown in Figure S4a (Supplementary Material) for samples of Exp. 4 (NaP1-NA and MgO). The SEM mapping analysis in Figure S4b (Supplementary Material), showed two crystals rich in $\mathrm{Mg}, \mathrm{P}, \mathrm{O}$ and $\mathrm{N}$. However, XRD analysis of the powdered mixture did not detect any crystal phosphate phase at ambient temperature or after thermal treatment at $1050^{\circ} \mathrm{C}$.

Measured total $\mathrm{PO}_{4}{ }^{3-}$ concentrations in the solution could not be explained by neither the formation of bobierrite (as in Exp. 1-3 working with stoichiometric Mg/P molar ratio) or the potential formation of Caphosphates. However, it could be explained by the formation of struvite (see Figure 6).

\section{Figure 6.}

The precipitation of struvite from side-streams using crystallization cycles has been widely reported. The use of $\mathrm{MgO}(\mathrm{s})$ as a magnesium source has the advantages of being environmentally friendly and essential for biological growth. Similarly, the high alkalinity of $\mathrm{MgO}(\mathrm{s})$ contributes to buffering the $\mathrm{pH}$ of the crystallization stage. While different studies reported the precipitation of struvite, other authors using $\mathrm{Mg}(\mathrm{OH})_{2}(\mathrm{~s})$ composites 
described phosphate removal by adsorption onto $\mathrm{Mg}(\mathrm{OH})_{2}(\mathrm{~s})$ surface groups by formation of the inner-sphere complex (Romero-Güiza et al., 2015; Romero-Güiza et al., 2016, 2014; Uludag-Demirer et al., 2008). Similar results were reported by Wang et al. (2015) with a hybrid biomaterial prepared by encapsulation of nano$\mathrm{Mg}(\mathrm{OH})_{2}(\mathrm{~s})$ onto discarded Artemia egg shells, which were evaluated as a slow-release fertilizer. Seedling tests further confirmed its properties for the soil improvement and crop productivity.

\subsection{Optimization of the N-P stabilization by using K-zeolites}

Although bio-solids are a source of the major plant nutrient elements (N, P, S, Mg, and Ca and trace elements such as $\mathrm{Cu}, \mathrm{Zn}$ and B) (Morera et al., 2002), they are not a significant source of $\mathrm{K}$ due to the elutriating effect of wastewater treatment on soluble components (Sánchez-Monedero et al., 2004). The benefits of ion exchange selectivity were evaluated between alkaline/earth-alkaline and $\mathrm{NH}_{4}{ }^{+}$ions as well as from previous studies with zeolites in $\mathrm{Ca}^{2+}$ form to $\mathrm{CaHPO}_{4} 2 \mathrm{H}_{2} \mathrm{O}$. The formation of more insoluble forms of phosphates as hydroxyapatite (Hermassi et al., 2016a; You et al., 2017) were also examined for the evaluation of K-zeolites to inhibit struvite precipitation and the formation of a high fertilizing form of $\mathrm{k}$-struvite $\left(\mathrm{KMgPO}_{4}(\mathrm{~s})\right)$. In order to explore the possibility of improving the fertilizing properties of the stabilization by-products in terms of Kcontent, the use of a synthetic zeolite in potassium form (5AH-IQE) was used.

Figure 7a shows, the progressive reduction of the phosphate and total ammonium concentration for Exp. 6 with continuous additions of $\mathrm{MgO}(\mathrm{s})$ (stages I-III) and K-zeolite (stages IV-VI). After the second addition (0.15 $\mathrm{g} / \mathrm{L}$ total $\mathrm{MgO}(\mathrm{s}))$ a final phosphate concentration of $0.1 \mathrm{mmol} / \mathrm{L}$ was reached, corresponding to $97 \%$ of recovery.

\section{Figure 7.}

As it is shown in Figure 8, measured values could be better described assuming the formation of bobierrite in comparison with the predicted values of the formation of the struvite. In comparison with Exp. 4 and 5, the addition of $\mathrm{MgO}(\mathrm{s})$ was performed in three stages to reach total concentrations of $\mathrm{MgO}(\mathrm{s})$ favouring the 
formation of struvite. At the end of the first $\mathrm{MgO}(\mathrm{s})$ addition, the $\mathrm{pH}$ was increased from $8.3 \pm 0.2$ to $9.5 \pm 0.2$, due to the basic properties of $\mathrm{MgO}(\mathrm{s})$, which is traduced on an increase of the phosphate removal.

Figure 8.

Moreover, the addition of $47 \mathrm{~g} / \mathrm{L}$ K-zeolite $(5 \mathrm{AH}-\mathrm{IQE})$ over three stages lead to a final concentration of ammonium at $3.6 \mathrm{mmol} / \mathrm{L}$ corresponding to above $90 \%$ of recovery (Figure 8 and Table 4). The ion-exchange reaction was confirmed by following the molar ratio (increase $\left(\mathrm{K}^{+} /\right.$decrease of $\left.\mathrm{NH}_{4}^{+}\right)$approached to 1 . For $\mathrm{pH}$ values $>9.3$, the ion-exchange capacity for ammonium diminishes due to the acid-base dependence as described by Eq. 3, so, $\mathrm{pH}$ was reduced to $\mathrm{pH} 8.5$ with a strong acid to favour the protonated form $\left(\mathrm{NH}_{4}{ }^{+}\right)$. $\mathrm{NH}_{4}{ }^{+}$cations are exchanged with $\mathrm{Na}^{+}$ions from the K-zeolite as stated by Eq. 4 :

ZO- $\mathrm{K}^{+}+\mathrm{NH}_{4}^{+} \leftrightarrow \mathrm{nZO}-\mathrm{NH}_{4}^{+}+\mathrm{K}^{+}$

Eq. 4

As described for previous experiments, XRD analysis of the powdered mixture did not detect any phosphate mineral phase. Table S1 (Supplementary Material shows the average compositions (\% mass) of the precipitates obtained in Exp. 6. Although reported previously in different studies, the formation of struvite $\left(\mathrm{MgNH}_{4} \mathrm{PO}_{4} \cdot 6 \mathrm{H}_{2} \mathrm{O}(\mathrm{s})\right)$ or struvite-k $\left(\mathrm{KMgPO}_{4}(\mathrm{~s})\right)$ (Ariyanto et al., 2014; Wilsenach et al., 2007) were not identified by DRX for the measured phosphate concentrations. Under the high content of zeolite on the reagents mixtures, phosphate minerals precipitated are below of the limit of detection.

Table 4. $\mathrm{N}$ and $\mathrm{P}$ concentrations and percentages of nutrients recovery at the end of each stage in Exp. 6 .

\begin{tabular}{ccccc}
\hline Stage & $\begin{array}{c}{\left[\mathrm{PO}_{4}{ }^{3-}\right]} \\
(\mathrm{mg} / \mathrm{L})\end{array}$ & $\begin{array}{c}{\left[\mathrm{NH}_{4}{ }^{+}\right]} \\
(\mathrm{mg} / \mathrm{L})\end{array}$ & $\mathrm{PO}_{4}{ }^{3-}$ recovery $(\%)$ & $\mathrm{NH}_{4}{ }^{+}$recovery $(\%)$ \\
\hline II & 125 & 567 & $56 \pm 3$ & $13 \pm 2$ \\
III & 28 & 525 & $78 \pm 2$ & $7.4 \pm 2$ \\
IV & 9.1 & 518 & $67 \pm 3$ & $1.3 \pm 1$ \\
V & n.d. & 120 & n.d. & $77 \pm 3$ \\
VI & n.d. & 109 & n.d. & $9.2 \pm 2$ \\
\hline Total & n.d. & 64 & n.d. & $41 \pm 2$ \\
n.d.: not detected & & & $>97 \pm 2$ & $90 \pm 4$ \\
\hline
\end{tabular}




\subsection{Recovery and stabilization of $\mathrm{N}$ and $\mathrm{P}$ as fertilizing by-products by using reactive sorbents}

Biosolids enriched with N, P, K containing loaded reactive sorbents could be applied in agriculture not only from an ecological point of view but also for economic and agronomical reasons. Therefore, waste management strategies are one of the most challenging aims for both soil and environmental science. An increasing number of attempts have been explored in the last years as it is summarized in Table 5.

Table 5. Comparison of reported studies on the recovery of nutrients $\mathrm{N}$ and $\mathrm{P}$ from urban, industrial and farming wastewaters by using reactive materials.

\begin{tabular}{|c|c|c|c|c|}
\hline Type of waste & Reactive materials used & Potential application & $\begin{array}{c}\text { Recovered nutrient } \\
\text { forms }\end{array}$ & Reference \\
\hline $\begin{array}{l}\text { Potassium-rich } \\
\text { sludge anaerobic } \\
\text { digestion side- } \\
\text { streams }\end{array}$ & $\begin{array}{c}\text { Powdered- } \\
\text { 1-Na-zeolite NaP1 } \\
\text { 2- } \mathrm{Ca}^{2} \text {-zeolite CaP1 } \\
\text { 3- Caustic magnesia (Magna L) }\end{array}$ & $\begin{array}{l}\text { The N-P-K-loaded sorbents } \\
\text { showed good nutrient release and } \\
\text { bioavailability ratios as co- } \\
\text { substrates for soil quality } \\
\text { improvement }\end{array}$ & $\begin{array}{l}\text { Brushite } \\
\text { Struvite } \\
\text { k-Struvite }\end{array}$ & $\begin{array}{l}\text { (Hermassi et } \\
\text { al., 2017a) }\end{array}$ \\
\hline Pig Slurry & $\begin{array}{l}\text { 1-Four industrial magnesium } \\
\text { oxide }(\mathrm{MgO}) \text {, a commercial } \\
\text { product and three by-products } \\
\text { from magnesite calcination. } \\
\text { 2- } \mathrm{PO}_{4}{ }^{3-} \text { was added as } \mathrm{K}_{2} \mathrm{HPO}_{4}\end{array}$ & $\begin{array}{l}\text { The study focused on the } \\
\text { underlying chemistry to show how } \\
\text { reactivity and dissolution of the } \\
\text { various magnesium by-products } \\
\text { influenced struvite precipitation } \\
\text { and inorganic nitrogen (TAN) } \\
\text { removal performance. }\end{array}$ & $\begin{array}{l}\text { Bobierrite } \\
\text { Newberyite } \\
\text { struvite }\end{array}$ & $\begin{array}{l}\text { (Romero- } \\
\text { Güiza et al., } \\
\text { 2015) }\end{array}$ \\
\hline $\begin{array}{l}\text { Treated } \\
\text { wastewater } \\
\text { effluents }\end{array}$ & $\begin{array}{l}\text { A sodium zeolite synthesized } \\
\text { from coal fly ash (NaP1-NA) } \\
\text { was } \\
\text { modified to calcium and } \\
\text { magnesium forms (Ze-Ca, Ze- } \\
\text { Mg) }\end{array}$ & $\begin{array}{l}\text { Loaded zeolites, which contain } \\
\text { ammonium and phosphate as well } \\
\text { as calcium or magnesium, could } \\
\text { be potentially used as slow- } \\
\text { release inorganic fertilizer }\end{array}$ & $\begin{array}{l}\text { Brushite } \\
\text { Struvite. }\end{array}$ & $\begin{array}{c}\text { (You et al., } \\
2017)\end{array}$ \\
\hline $\begin{array}{l}\text { Treated waste } \\
\text { water }\end{array}$ & $\begin{array}{l}\text { Two different types of Fly ashes } \\
\text { from two coal power stations } \\
\text { with different CaO(s) contents } \\
\text { (Los Barrios (FA-LB }(2.8 \% \text { w)) } \\
\text { and Teruel (FA-TE }(4.8 \% \text { w))) }\end{array}$ & $\begin{array}{l}\text { Potential fertilizer, even in } \\
\text { calcareous soils. }\end{array}$ & Brushite & $\begin{array}{l}\text { (Hermassi et } \\
\text { al., 2017b) }\end{array}$ \\
\hline
\end{tabular}

In general, wastes generated from industrial processes (e.g., coal and biomass combustion fly ash, industrial sludge or mineral tailings) or low-cost natural sorbents have been used. The main rationale for the selection of the materials is the high content of $\mathrm{Mg}$ or Ca minerals (oxides), carbonates or silicates to promote the recovery of $\mathrm{Mg}$ - and Ca-phosphates minerals. In the case of ammonium, the main option is the use of selective ionexchange materials. The widely adopted solution is the use of natural or synthetic zeolites. Only recently 
Romero-Gúiza et al. (2014), proposed the use of $\mathrm{MgHPO}_{4}(\mathrm{~s})$ as a precursor for the formation of struvite $\left(\mathrm{MgNH}_{4} \mathrm{PO}_{4}(\mathrm{~s})\right)$.

In this study, the cost of the nutrients' recovery was estimated in terms of reagents consumption (MgO, $\mathrm{NaP1})$. The cost of recovery was expressed as a cost of treated digestate $\left(€ / \mathrm{m}^{3}\right)$, as a cost in euros per $\mathrm{kg}$ of recovered $N(€ / \mathrm{kg} \mathrm{N})$, and as a cost in euros per $\mathrm{kg}$ of $P$ recovered $(€ / \mathrm{kg} P)$. The reagents cost was obtained from market data. The cost of MgO varies between 130-200 €/t (Valle-Zermen et al., 2016) and between 80 and $110 € /$ ton for natural zeolites (Inglezakis and Zorpas, 2012). The cost associated with reagents added for fixing $\mathrm{pH}$ has not been considered as it was demonstrated that it is not a critical factor when taking into account that the alkalinity of the anaerobic digestates provides a high buffer capacity. Digestates streams with ammonia concentrations of 0.6 to $1 \mathrm{~kg} \mathrm{~N} / \mathrm{m}^{3}$ and phosphate concentrations of 0.2 to $0.3 \mathrm{kgP} / \mathrm{m}^{3}$, reagent doses of $0.15 \mathrm{~g} \mathrm{MgO} / \mathrm{m}^{3}$, and $30 \mathrm{~kg}$ zeolite $/ \mathrm{m}^{3}$ were assumed for cost estimates. The recovery cost associated with $P$ was $0.1 € / \mathrm{kg} P$ and the cost associated with $N$ was $3.0 € / \mathrm{kg} \mathrm{N}$, yielding a total cost of $3.1 € / \mathrm{m}^{3}$ of treated digestate. If the cost of the stabilized nutrients $(\mathrm{N}$ and $\mathrm{P})$ are accounted for in terms of prices of fertilizers $(0.28$ $€ / \mathrm{kg} \mathrm{N}$ and $2.37 € / \mathrm{kg} \mathrm{P}$ ), the benefit provided to the non-digested sludge is estimated as $0.59 € / \mathrm{m}^{3}$ of treated water providing a net value of $2.5 € / \mathrm{m}^{3}$ of digestate (LeBlanc et al., 2009).

As the major cost is associated with the recovery of ammonia, this cost was compared with the existing $\mathrm{N}$ management technologies considering the removal and recovery ratios similar to those achieved in this study (60 to $90 \%$ ). The removal of ammonium from digestate side-streams by using Anammox is reported to have an associated cost of $0.8-1.1 € / \mathrm{kg} \mathrm{N}$ removed, and the recovery technologies using air stripping reported values between 1 to $4 € / \mathrm{kg} \mathrm{N}$ recovered (Stamatelatou and Tsagarakis, 2015). These values included the investment costs, which were not considered in the present study. The associated investment cost, mainly dosing equipment of $\mathrm{MgO}$ (s) and $\mathrm{Na}$-Zeolite, is very limited when compared to the air stripping technologies. If the recovery of nutrients by reactive sorbents is associated to good agronomical application practices, the proposed approach could be considered as a feasible management option when criteria for nutrients recovery are imposed. 
Although adding nutrient-loaded sorbents to soil improves agricultural yields and nutritional qualities, socioeconomic conditions will determine whether the materials can be applied to commercial agriculture. The key issues that influence the application of post-sorbent fertilizers are the availability of feedstocks, the technology to manufacture fertilizers, and the investment capacity. Further economic analyses of the use of post-sorbent fertilizers will determine the feasibility of applying these materials to agricultural systems. Therefore, the characterization of the soils supplied with different organic fertilizers over a long period of time is imperative. In order to conveniently establish pathways to recycle these residues as fertilizers, an economically and environmentally friendly alternative to storage and incineration must be identified.

The challenge of the widely adopted organic based fertilizers (e.g., mixtures of digested sewage sludge, manure based sludge, organic wastes enriched with nutrients $(N, P, K))$ is to ensure that their application is not resulting in an accumulation of different organic non-biogenic and inorganic compounds (e.g., toxic metals and non-metals). As their accumulation may cause hazardous effects, which are either not yet known or well understood; studies of plant growth validation at pot level in greenhouses up to field validation at full scale are needed. The existence of specific regulations and regulators to provide bio-solids certification for potential uses in agriculture is being developed in the UK as a way to extend their safe use and application.

\section{Conclusions}

The recovery and stabilization of phosphate and ammonium from urban sludge anaerobic digestates as $P$ and $\mathrm{N}$ sources for soil fertilization application using reactive sorbents was evaluated in this work. The use of $\mathrm{MgO}(\mathrm{s})$ as a source for $\mathrm{Mg}$ to promote the stabilization of phosphate ions as bobierrite or struvite was found efficient. Doses with stoichiometric molar ratio of $\mathrm{Mg} / \mathrm{P}$ promoted the formation of bobierrite, while molar ratios higher than 3 favoured the formation of struvite.

$\mathrm{Na}$ and $\mathrm{K}$ Zeolites demonstrated efficient ammonium stabilization on the crystal structure, but it is limited by the zeolite sorption capacity. It was demonstrated that doses of $15 \mathrm{gNaP} 1 / \mathrm{L}$ provide recovery ratios of stabilized ammonium up to $60 \pm 5 \%$ while doses of $22.3 \mathrm{gNaP} 1 / \mathrm{L}$ provide recovery ratios up to $91 \pm 3$. If the $\mathrm{N}$ 
and $\mathrm{P}$ additive for soil improvement needs to be enriched by $\mathrm{K}$, then the use of K-zeolite could provide a good solution as demonstrated by the use of a K-zeolite (5AH-IQE).

The maximum recovery ratios can be reached when the $\mathrm{pH}$ is controlled. While the optimum $\mathrm{pH}$ to achieve the formation of struvite and bobierrite is approximately 9.5 , the optimum $\mathrm{pH}$ conditions to achieve the maximum recovery of ammonium is in the range between 4 and 8.5 , as the total ammonium concentration is present in a higher concentration of $\mathrm{NH}_{4}{ }^{+}$. Therefore, the criteria for operation will be to maintain $\mathrm{pH}$ between 8.2 and 8.6, values that are typically obtained for anaerobic digestates. The criteria will depend only on the excess of zeolite or $\mathrm{MgO}(\mathrm{s})$ used. Considering that both reactive sorbents (( $\mathrm{MgO}(\mathrm{s})$ and $\mathrm{Na}, \mathrm{K}$ zeolites) have basic properties, it is recommended to reduce the $\mathrm{pH}$ by a strong acid (e.g., $\mathrm{H}_{2} \mathrm{SO}_{4}$ ) to optimize the ammonium stabilization.

Work in development is aimed to improve materials prepared when designing nutrient-loaded sorbent fertilizers properties: i) affinity for both cations and anions $\left(\mathrm{NH}_{4}^{+}, \mathrm{K}^{+}, \mathrm{NO}_{3}{ }^{-}\right.$, and $\left.\mathrm{PO}_{4}{ }^{3-}\right)$, ii) stability under soil environmental conditions, iii) slow-release characteristics, (iv) water-holding capacity, and v) ability to function for long periods.

\section{Acknowledgments}

This study has been supported by the ZERODISCHARGE project (CTQ2011-26799) and the Waste2Product project (CTM2014-57302-R) financed by Ministry of Science and Innovation (MINECO, Spain) and the Catalan government (project ref. 2014SGR050). We wish to thanks, I. Lopez (Laboratory of Electronic Microscopy, CMEM-UPC) for the FSEM analysis and to Francisco Cacho from Industrias Quimicas del Ebro (Zaragoza Spain) for samples supply.

\section{References}

Álvarez, J., Roca, M., Valderrama, C., Cortina J. L., A Phosphorous Flow Analysis in Spain, Sci. Total Environ. 612 (2018) 995-1006.

APHA, AWWA, and WEF,"Standard Method for the Examination of Water and Waste Water", Washington DC, 20th edition., (1999). 
Ariyanto, E., Sen, T.K, Ang, H.M, 2014. The influence of various physico-chemical process parameters on kinetics and growth mechanism of struvite crystallisation. Adv. Powder Technol. 25 (2014) 682-694.

Batstone, D.J., Virdis, B., 2014. The role of anaerobic digestion in the emerging energy economy. Curr. Opin. Biotechnol. 27, 142-149.

Fabrizio, A., Fulvia, T., 2005. Long-term effect of sewage sludge application on soil humic acids. Chemosphere 60, 1214-1221.

Fux, C., 2003. Biological nitrogen elimination of ammonium-rich sludge digester liquids. PhD thesis, ETHZürich, Switz.

Gray-Munro, J.E., Strong, M., 2013. A study on the interfacial chemistry of magnesium hydroxide surfaces in aqueous phosphate solutions: influence of $\mathrm{Ca}^{2+}, \mathrm{Cl}^{-}$and protein. J. Colloid Interface Sci. 393, 421-428.

Hermassi, M., Moreno, N., Font, O., Querol, X., Batis Harrouch, N., Cortina, J.L., 2016a. Powdered Caactivated zeolite for phosphate removal from treated waste-water. J Chem Technol Biotechnol 91, 19621971.

Hermassi, M., Valderrama, C., Dosta, J., Cortina, J.L., Batis, N.H., 2016b. Detrimental effects of magnesium (II) on hydroxyapatite precipitation from synthetic industrial brines. Chem. Eng. J. 283, 572-581.

Hermassi, M., Valderrama, C., Gibert, O., Moreno, N., Querol, X., Batis, N.H., Cortina, J.L., 2017a. Recovery of nutrients ( N-P-K ) from potassium-rich sludge anaerobic digestion side-streams by integration of a hybrid sorption-membrane ultra fi Itration process : Use of powder reactive sorbents as nutrient carriers. Sci. Total Environ. 599-600, 422-430.

Hermassi, M., Valderrama, C., Moreno, N., Font, O., Querol, X., Harrouch Batis, N.C.J.L., 2017b. Fly ash as reactive sorbent for phosphate removal from treated waste water as a potential slow release fertilizer. J. Environ. Chem. Eng. 5, 160-169.

Inglezakis, V.J., Zorpas, A.A., Handbook of Natural Zeolites, Bentham Science Publishers, (2012). 
LeBlanc, R.J., Matthews, P., Richard, R.P., Global Atlas of Excreta, Wastewater Sludge, and Biosolids Management: Moving Forward the Sustainable and Welcome Uses of a Global Resource, (2009).

Li, Z., Zhang, Y., Li, Y., 2013. Zeolite as slow release fertilizer on spinach yields and quality in a greenhouse test. J. Plant Nutr. 36, 1496-1505.

Malingreau, J., Eva, H., Maggio,A., NPK: Will there be enough plant nutrients to feed a world of 9 billion in 2050 ? Foresight and Horizon Scanning Series. Research Centre of the European Commission. (JRC70936), (2012) 10-32.

Mathews, A.P., Weber, J., Jr. Effect of external mass transfer and interparticle diffusion on adsorption rates in slurry reactors, AICHE Symp.Ser. 73 (166), 91 (1976).

Milieu, WRC, RPA, Environmental, economic and social impacts of the use of sewage sludge on land. Final Report - Part III: Project Interim Reports. Service contract No 070307/2008/517358/ETU/G4 , (2013) 1 266.

Morera, M.T., Echeverría, J., Garrido, J., 2002. Bioavailability of heavy metals in soils amended with sewage sludge. Can. J. SOIL Sci. 82, 433-438.

Nordstrom, D.K., Plummer, L.N., Langmuir, D., E. Busenberg, H.M. May, B.F. Jones, D.L. Parkhurst, Revised Chemical Equilibrium Data for Major Water — Mineral Reactions and Their Limitations, ACS Symp. Ser. Am. Chem. Soc. 416 (1990) 398-413.

Puidomènech, I.S.S., 2001. Chemical Equilibrium Software Hydra and Medusa. Stock. Sweden.

Querol, X., Moreno, N., Alastuey, A., Juan, R., Ayora, C., Medinaceli, A., Valero, A., Productos, C., 2007. Synthesis of high ion exchange zeolites from coal fly ash. Geol. Acta 5, 49-57.

Romero-Güiza, M.S., Astals, S., Chimenos, J.M., Martínez, M., Mata-alvarez, J., 2014. ScienceDirect Improving anaerobic digestion of pig manure by adding in the same reactor a stabilizing agent formulated with low-grade magnesium oxide. Biomass and Bioenergy 67, 243-251. 
Romero-güiza, M.S., Astals, S., Mata-alvarez, J., Chimenos, J.M., 2015. Feasibility of coupling anaerobic digestion and struvite precipitation in the same reactor : Evaluation of different magnesium sources. Chem. Eng. J. 270, 542-548.

Romero-Güiza, M.S., Vila, J., Mata-alvarez, J., Chimenos, J.M., Astals, S., 2016. The role of additives on anaerobic digestion : A review. Renew. Sustain. Energy Rev. 58, 1486-1499.

Sánchez-Monedero, M.A., Mondini, C., Nobili, M. De, Leita, L., Roig, A., Sa, M.A., 2004. Land application of biosolids . Soil response to different stabilization degree of the treated organic matter 24, 325-332.

Stamatelatou, K., Tsagarakis, K.P., Sewage Treatment Plants: Economic Evaluation of Innovative Technologies for Energy Efficiency, in: Integr. Environ. Technol. Ser. IWA Publ., (2015) 296-298. ISBN 9781780405018.

Uludag-Demirer, S., Demirer, G.N., Frear, C., Chen, S., 2008. Anaerobic digestion of dairy manure with enhanced ammonia removal 86, 193-200.

Valle-Zermen, Formosa, R.J., Go, J., Chimenos, J.M., Desulfurization Performance of MgO Byproducts as a Function of Particle Size, Energy Fuels 2016,. 30 (2016) 2328-2335.

Wang, S., Ma, M., Zhang, Q., Sun, G., Jiao, T., Okazaki, R.K., 2015. Efficient Phosphate Sequestration in Waters by The Unique Hierarchical 3D Artemia Egg Shell Supported Nano-Mg(OH)2 Composite and Sequenced Potential Application in Slow Release Fertilizer. ACS Sustain. Chem. Eng 3, 2496-2503.

Wendling, L. a., Blomberg, P., Sarlin, T., Priha, O., Arnold, M., 2013. Phosphorus sorption and recovery using mineral-based materials: Sorption mechanisms and potential phytoavailability. Appl. Geochemistry 37, 157-169.

Wilsenach, J.A., Schuurbiers, C.A.H., van Loosdrecht, M.C.M., 2007. Phosphate and potassium recovery from source separated urine through struvite precipitation. Water Res. 41, 458-466.

You, X., Valderrama, C., Cortina, J.L., 2017. Simultaneous recovery of ammonium and phosphate from 
simulated treated wastewater effluents by activated calcium and magnesium zeolites. Chem. Technol.

Biotechnol. doi: 10.1002/jctb.5249

\section{Annex 1.}

\section{Homogeneous surface diffusion model}

To describe the process mechanisms of sorption, the homogeneous surface diffusion model (HSDM) has been developed and analysed by several researchers. In this study, the HSDM was employed to determine the maximum of amount of zeolite that can be used to obtain the higher nutrients recovery according to the experiments described in section 2.2. The basis of this model was proposed by Mathews and Weber (1976) and included the effect of external mass transfer, unsteady-state surface diffusion in the particle and a nonlinear adsorption isotherm. The assumptions of HSDM are:

1- The adsorbent particle is assumed to be a homogenous solid sphere in which the adsorbate is transported by surface diffusion.

2- $\quad$ The rate-controlling process is mass transport by film and surface diffusion only.

3- $\quad$ A driving force describes the liquid film resistance to mass transfer at the outer surface of the particle.

4- Instantaneous equilibrium between the PZ and the adsorbate occurs at the outer surface of the PZ.

The equations describing the homogeneous surface diffusion model are listed in Table A1. A plot of the ratio $\left(\mathrm{C} / \mathrm{C}_{0}\right)$ of adsorbate or percentage of adsorbate remaining in the water as a function of adsorbent dose at any contact time is independent of the initial adsorbate concentration if the diffusion coefficient is not a function of test conditions. These tests should be conducted for each desired contact time, assuming the same amount of zeolite $(\mathrm{g} / \mathrm{L})$ with the same background nutrient concentration. 
Table A1. Equations for the homogeneous surface diffusion model.

\begin{tabular}{|lc|}
\hline \multicolumn{1}{|c|}{ Equation } & Role \\
\hline$\frac{d C_{b}}{d t} \mathrm{~V}=-\mathrm{M} \frac{d_{q_{\text {avg }}}}{d t}$ & Masse balance for closed batch test \\
$q_{a v g}=\frac{3}{\left(\frac{d p}{2}\right)^{3}} \int_{0}^{d_{p} / 2} q(r . t) r^{2} d r$ & Average zeolite load \\
$\frac{\partial q}{\partial t}=\frac{D_{s}}{r^{2}} \frac{\partial}{\partial r}\left(r^{2} \frac{\partial q}{\partial r}\right)$ & Diffusion equation for a spherical particle \\
$q(\mathrm{r} .0)=0$ & Initial condition \\
$\frac{\partial q}{\partial t}=0$ for $r=0$ & Boundary condition for the center of the spherical particle $\rho_{p} D_{s} \frac{\partial q}{\partial r}=$ \\
$K_{f}\left(C_{b}-C_{s}\right)$ & Boundary condition for continuity of flux at $\mathrm{r}=\frac{d_{p}}{2}$ \\
$q_{s}=K C_{s}{ }^{n}$ & Freundlich isotherm for equilibrium at solid-liquid interface \\
\hline
\end{tabular}



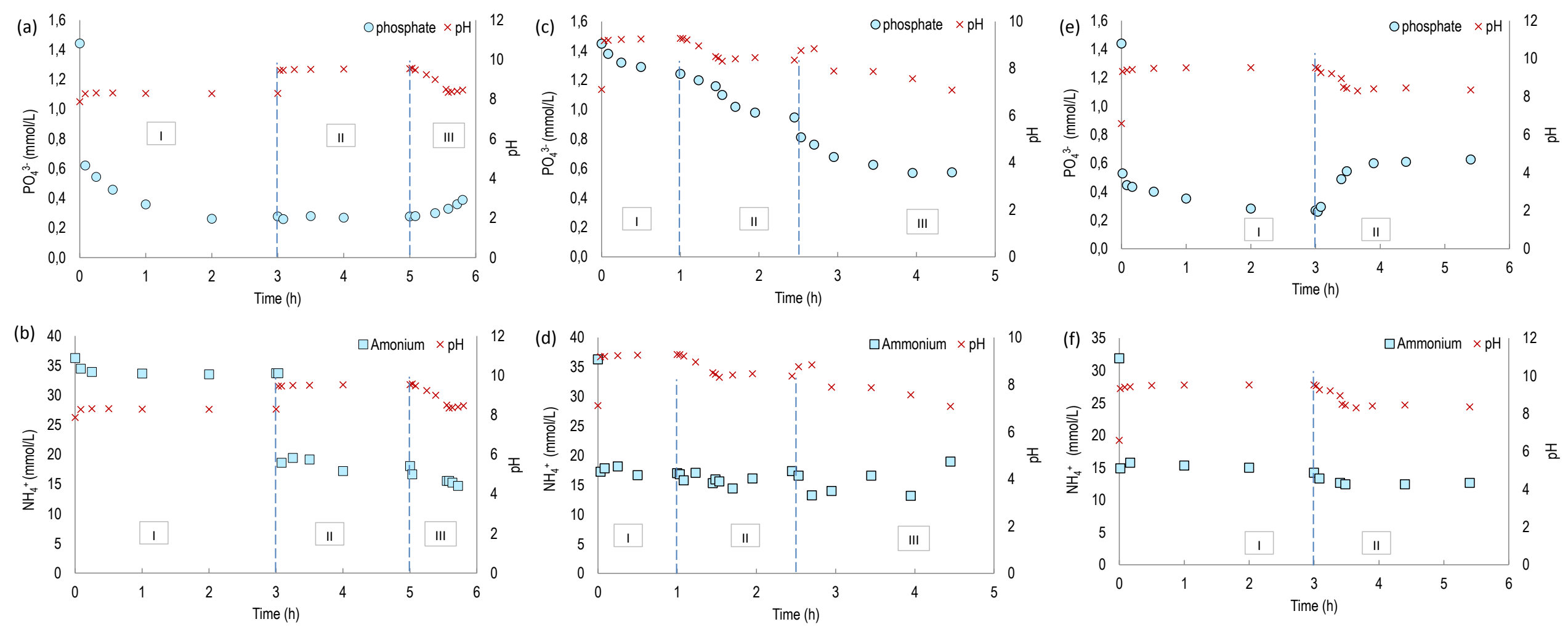

Figure 1. Evolution of phosphate, total ammonium concentration as pH as a function of contact time along three consecutives cycles in Exp. 1 (a, b), Exp. 2 (c, d) and Exp. 3 (e, f). The operating conditions of the experiments are listed in Table 2 (the Roman numerals correspond to the number of stages). 


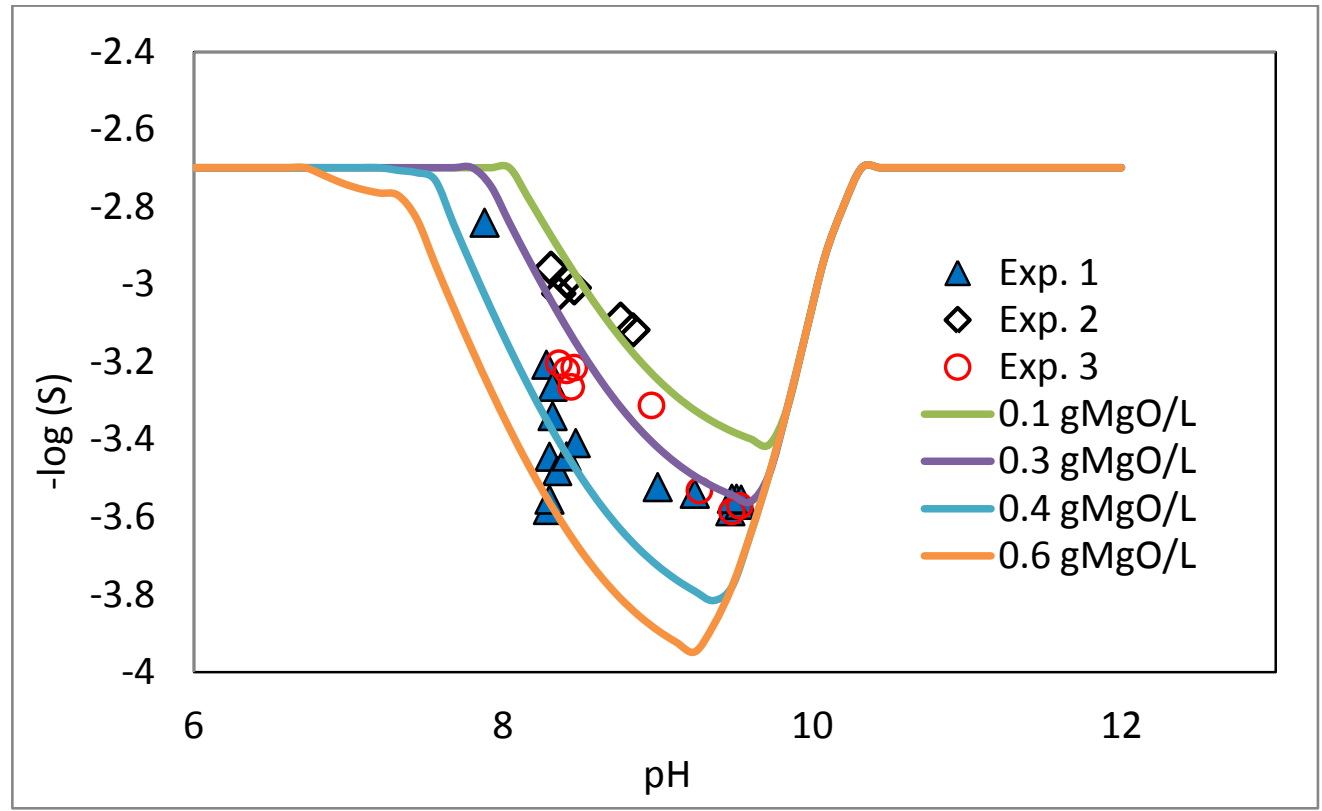

Figure 2. Variation of measured total phosphate (Ptot) concentrations with $\mathrm{pH}$ and total phosphate concentration in equilibrium, represented as logarithmic values solubility $(\operatorname{logS})$, of bioberrite $\left(\mathrm{Mg}_{3}\left(\mathrm{PO}_{4}\right)_{2}\right.$ using the HYDRA-MEDUSA Code and represented by solid lines. Bobierrite solubility curves were constructed as a function of total $\mathrm{MgO}(\mathrm{s})$ concentration (namely, $0.1,0.3,0.4$ and $0.6 \mathrm{~g} \mathrm{MgO} / \mathrm{L}$ ). 
(a)
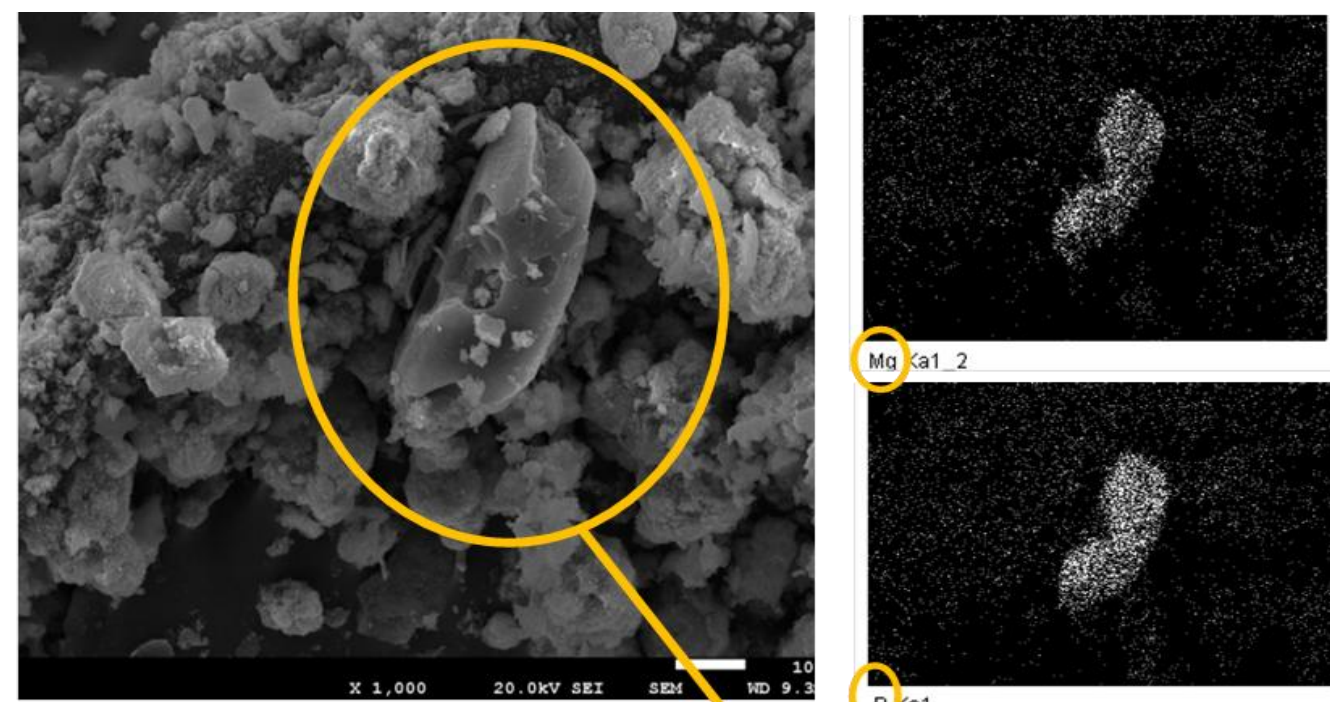

Mg রa1_2

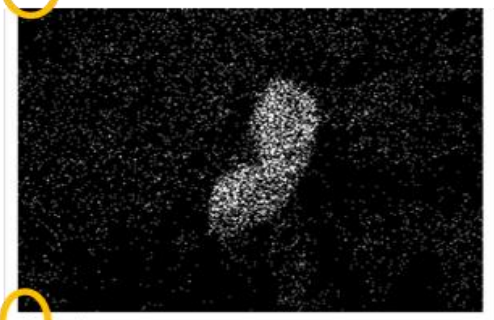

$\times 1,000$

20. OKV SEI

P <a1

Magnesium Phosphate

(b)

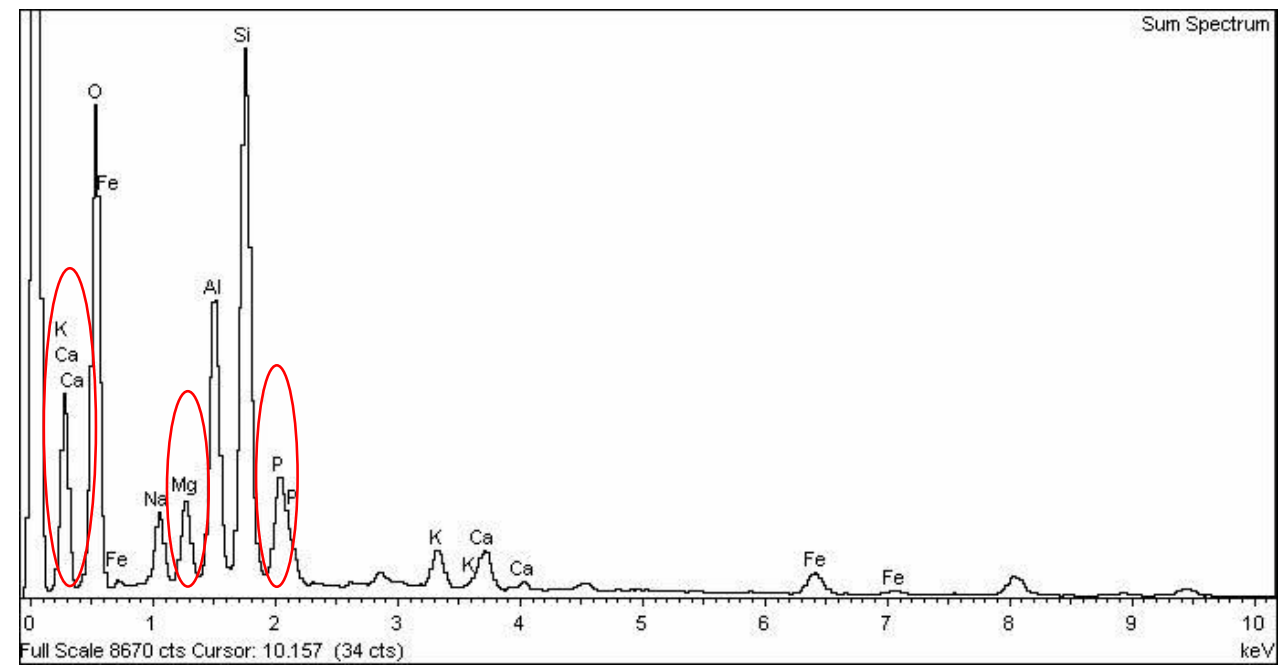

Figure 3. Morphology of samples from Exp. 2 ( $\mathrm{NaP1} / \mathrm{MgO}(\mathrm{s}) /$ constant $\mathrm{pH})$ by a) SEM-EDAX mapping analysis and b) Energy Dispersive X-ray (EDX) spectra of crystal circled. 


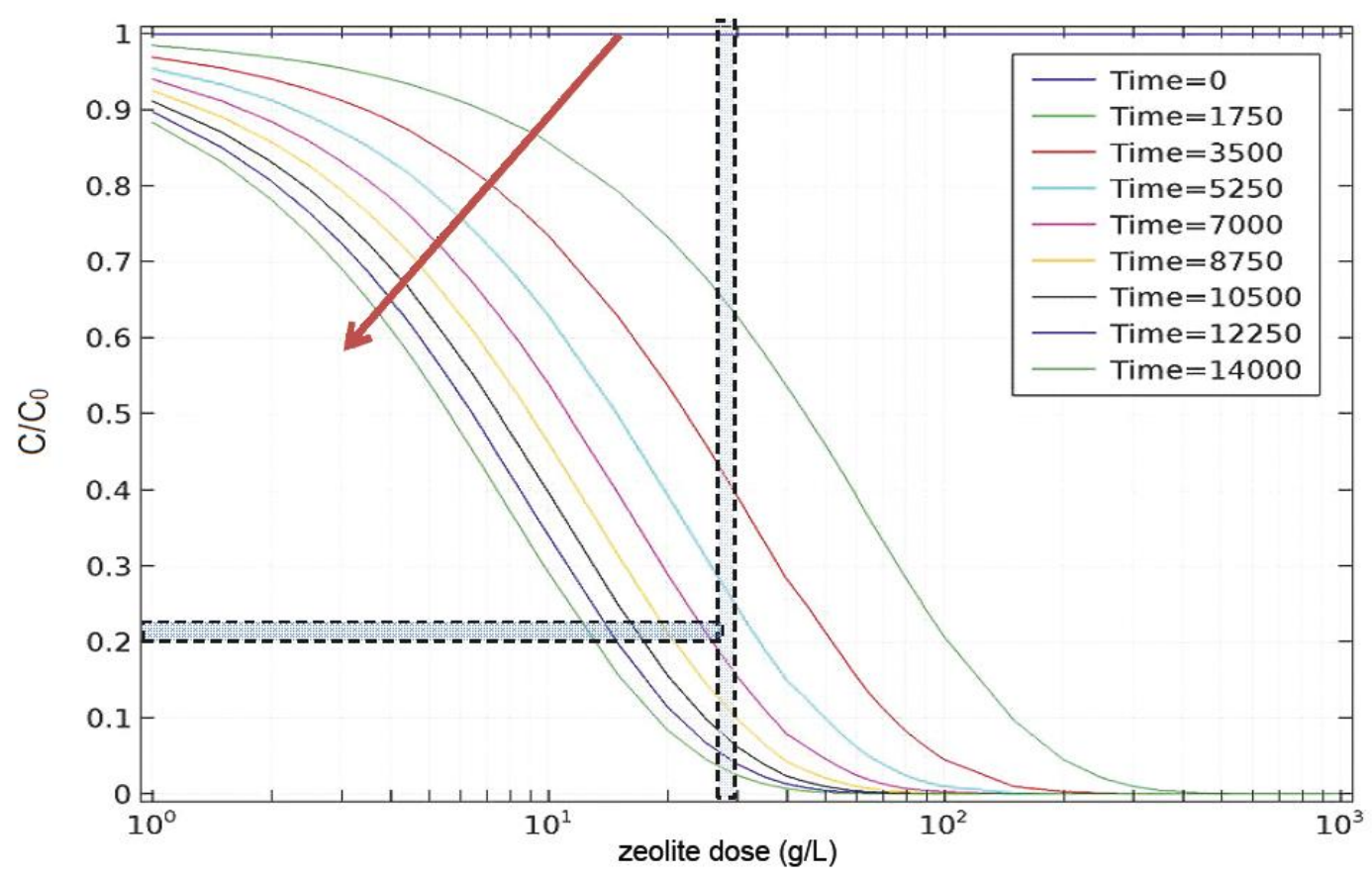

Figure 4. Variation of the ammonium recovery $\left(a \mathrm{C} / \mathrm{C}_{0}\right)$ for a stirred tank reactor as a function of the zeolite dose (g zeolite /L). Solid lines were calculated using the Homogeneous Diffusion Model (HSDM) $\left(K_{\mathrm{f}}=2.210^{-8} \mathrm{~m} / \mathrm{s} ; \mathrm{Ds}=1.0810^{-11} \mathrm{~m}^{2} / \mathrm{s}\right.$, Initial concentration=600 mg/L, Volume $=1.5 \mathrm{~L}$, Zeolite weight= $32 \mathrm{~g})$. In this Figure, time is expressed in seconds. 

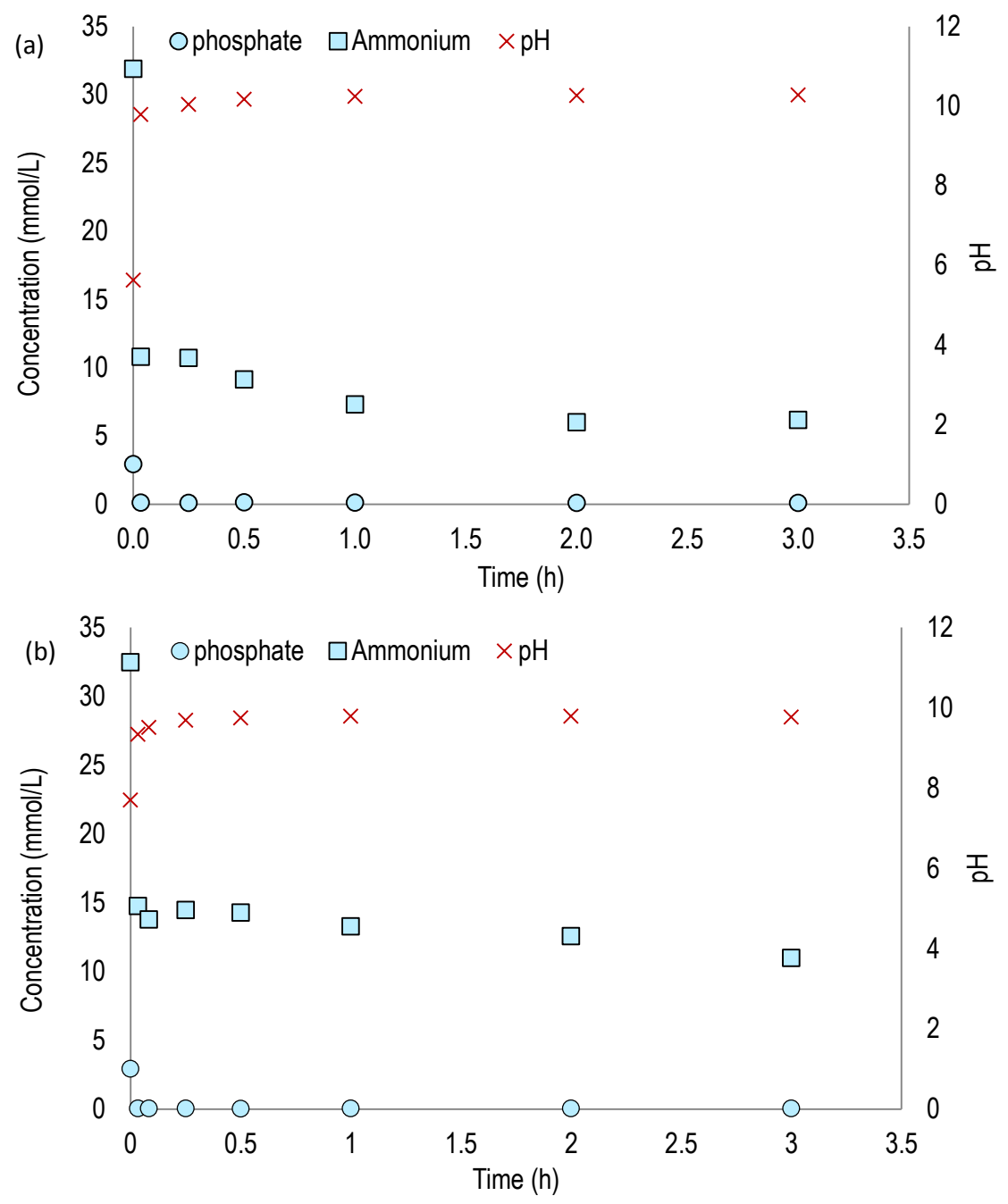

Figure 5. Monitoring of ammonium concentration, phosphate concentration and $\mathrm{pH}$ using a) NaP1-NA zeolite with a molar ratio $\mathrm{MgO}: \mathrm{PO}_{4}^{3-}(3: 1)$ (Exp. 4); and b) $\mathrm{NaP} 1-\mathrm{IQE}$ zeolite with a molar ratio $\mathrm{MgO}$ : $\mathrm{PO}_{4}^{3-}(3: 1)$ (Exp. 5). 


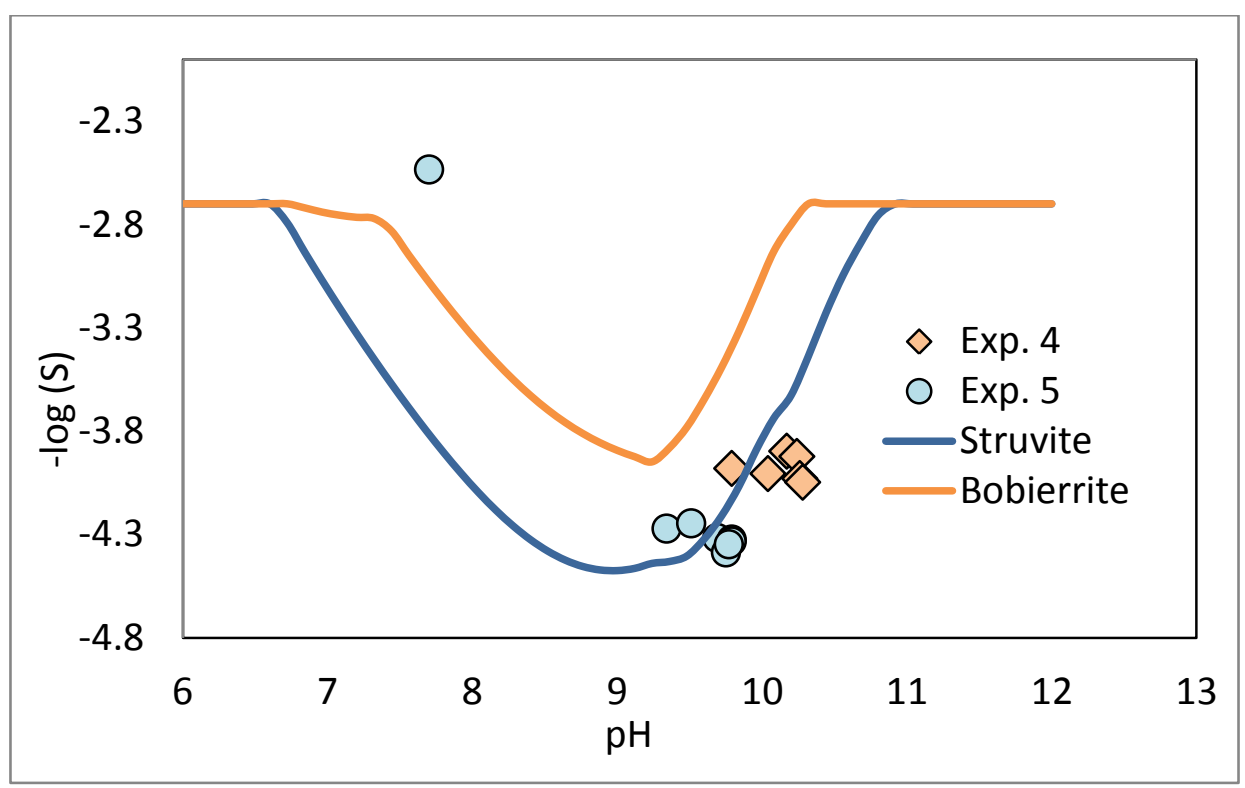

Figure 6. Variation of measured (points) and predicted (solid lines) total phosphate (Ptot) concentrations represented as logarithmic values of solubility (logS). Predicted values were modelled assuming the formation of bobierrite $\left(\mathrm{Mg}_{3}\left(\mathrm{PO}_{4}\right)_{2}(\mathrm{~s})\right)$ and struvite $\left(\mathrm{MgNH}_{4} \mathrm{PO}_{4}(\mathrm{~s})\right)$ using the HYDRA-MEDUSA Code as a function of $\mathrm{pH}$. 

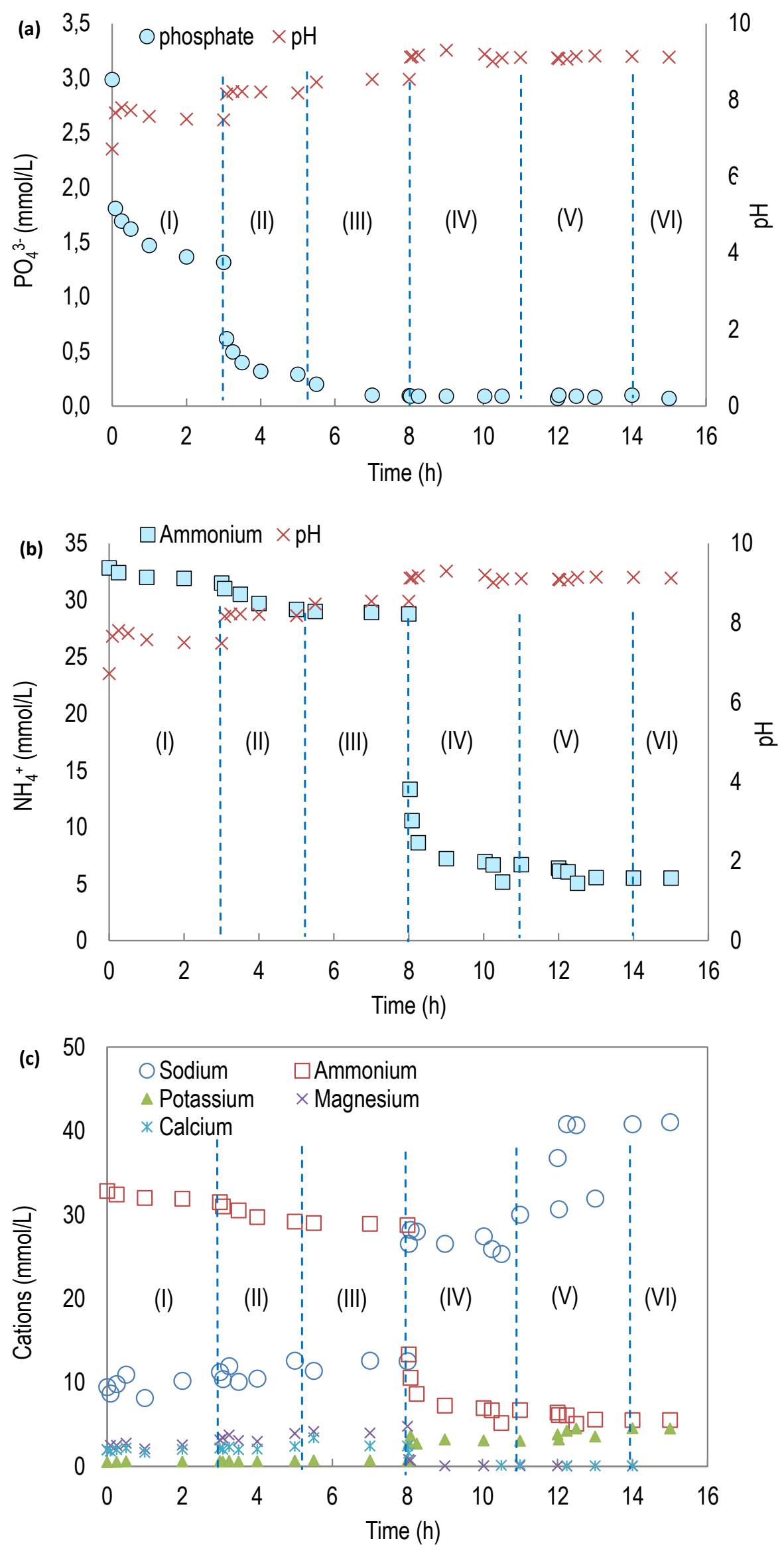
Figure 7. Evolution of $\mathrm{pH}$ and a) phosphate and b) ammonium concentrations and c) the cations concentration as a function of time using 5AH-IQE zeolite (50/10/10 g) (Exp. 6). The Roman numerals (I to $\mathrm{VI})$ correspond to the number of stages as described in Table 2.

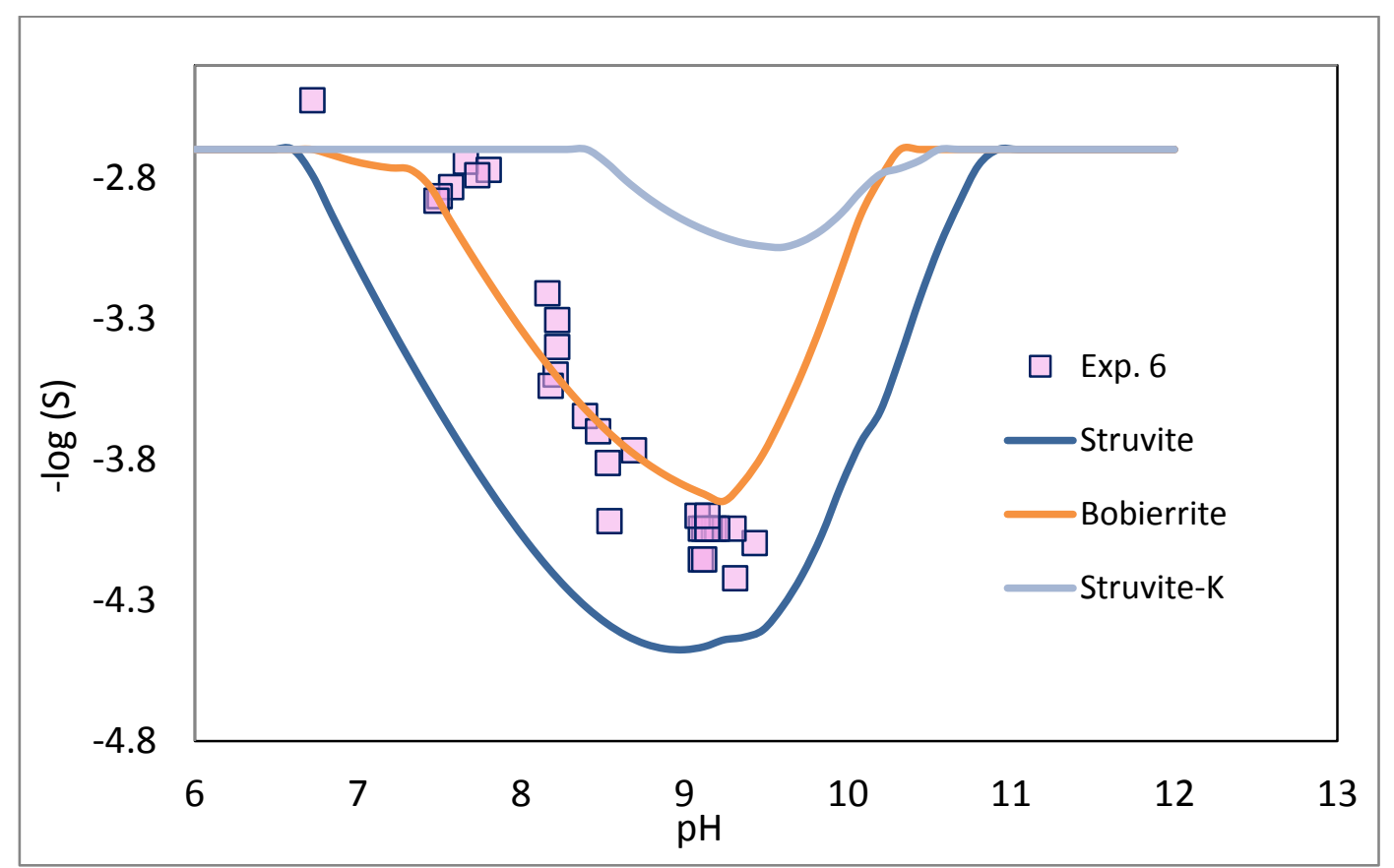

Figure 8. Variation of measured (points) and predicted (solid lines) total phosphate (Ptot) concentrations represented as logarithmic values of solubility (logS). Predicted values were modelled assuming the formation of Struvite- $\mathrm{K}\left(\mathrm{KMgPO}_{4} \cdot 6 \mathrm{H} 2 \mathrm{O}\right)$, bobierrite $\left(\mathrm{Mg}_{3}\left(\mathrm{PO}_{4}\right)_{2}(\mathrm{~s})\right)$ and struvite $\left(\mathrm{MgNH}_{4} \mathrm{PO}_{4}(\mathrm{~s})\right)$ using the HYDRA-MEDUSA Code as a function of $\mathrm{pH}$. 